\title{
New Parameterization of a Global Vegetation Model for Steppe Ecosystem From Southern Siberian In Situ Measurements
}

\author{
Nicolas Vuichard, ${ }^{1,2}$ Philippe Ciais, ${ }^{3}$ Luca Belelli-Marchesini, ${ }^{1}$ and Riccardo Valentini ${ }^{4}$
}

\begin{abstract}
Authors are ${ }^{1}$ Researchers and ${ }^{4}$ Professor, Department of Forest Resources and Environment, University of Tuscia, Via San Camillo de Lellis, 01100 Viterbo, Italy; ${ }^{2}$ Researcher, Centre International de Recherche sur l'Environnement et le Développement-Centre National de la Recherche Scientifiquel Ecole des Hautes Etudes en Sciences Sociales (CNRS/EHESS), Nogent sur Marne, France; and ${ }^{3}$ Researcher, Laboratoire des Sciences du Climat et de l'Environnement, Institut Pierre Simon Laplace-Commissariat à l'Energie Atomique (IPSL-CEA)/CNRS, Saclay, France.
\end{abstract}

\begin{abstract}
This article presents a new parameterization of the global vegetation organizing carbon and hydrology in dynamic ecosystems (ORCHIDEE) model, modifying the assimilation, allocation, and phenology processes for a steppe ecosystem. It aims 1) to improve the modeled growth primary production (GPP) based on both in situ $\mathrm{CO}_{2}$ flux measurements and remote-sensing data of the fraction of absorbed photosynthetic radiation, and 2) to evaluate how GPP improvement results in better-modeled fluxes for ecosystem respiration, net ecosystem exchange, and latent heat. This new parameterization leads to a realistic annual GPP (comparable to the data within $10 \%$ ), and a realistic seasonal variability of GPP $\left(R^{2}=0.80\right)$. Further, we found that improving GPP into ORCHIDEE immediately brings ecosystem respiration and net ecosystem exchange fluxes into better agreement with the eddy-covariance data, both on seasonal but also on interannual time scales. This result suggests that the response of this steppe ecosystem to interannual climate variations can be well reproduced from the response to seasonal variation, and that biotic effects are not interannual. This indicates the potential ability to reproduce climate-induced changes in the carbon balance of steppes with the use of a generic process-oriented vegetation model such as ORCHIDEE.
\end{abstract}

\section{Resumen}

Este trabajo presenta una nueva configuración del modelo de vegetación global ORCHIDEE modificando los procesos de asimilación, asignación y fenología para ecosistemas de estepa. Apunta a 1) mejorar la representación de la Productividad Primaria de Crecimiento basada tanto en mediciones locales del flujo de $\mathrm{CO} 2$ y en datos de la Fracción de Radiación Fotosintética Absorbida proveniente de sensores remotos y, 2) evaluar como la mejora en PPC influye sobre la simulación de flujos de Respiración del Ecosistema, el Intercambio Neto del Ecosistema, y el Calor Latente. Esta nueva configuración da como resultado una PPC más realista (dentro del 10\% del valor de los datos), y una variación estacional realista de la PPC $(\mathrm{R} 2=0.80)$. Además, encontramos que la mejora en las estimaciones de PPC en ORCHIDEE inmediatamente incrementa la concordancia ente los flujos simulados de Respiración del Ecosistema y el Intercambio Neto del Ecosistema con los datos de Eddy-covarianza, a escalas de tiempo no solo estacionales sino que también interanuales. Este resultado sugiere que la respuesta de este ecosistema de estepa a variaciones climáticas interanuales puede ser reproducida correctamente a partir de respuestas estacionales y que los efectos bióticos no son interanuales. Esto provee esperanzas de poder reproducir cambios inducidos en el balance de carbono de las estepas utilizando un modelo de procesos genérico tal como el ORCHIDEE.

Key Words: carbon fluxes, model parameterization, steppe

\section{INTRODUCTION}

The Eurasian steppe ecosystem covers 8 million $\mathrm{km}^{2}$, the largest area of grassland ecosystems globally. Central Asian steppes in Mongolia, Baikal area, Altai, Hakassia, and Tuva republics alone sum up to 2.23 million $\mathrm{km}^{2}$. Steppe is thus the dominant ecosystem in Central Asia, and globally important for understanding the carbon cycle. In addition, this ecosystem is

Research was funded in part by the CARBOEUROPE-IP European project GOCE-CT-2003505572.

This publication was made possible through support provided to the Global Livestock Collaborative Research Support Program by the Office of Agriculture, Bureau for Economic Growth, Agriculture and Trade, United States Agency for International Development under terms of Grant No. PCE-G-00-98-00036-00. The opinions expressed herein are those of the author(s) and do not necessarily reflect the views of the USAID.

Correspondence: Nicolas Vuichard, Centre International de Recherche sur l'Environnement et le Développement-CNRS/EHESS, Nogent sur Marne, France. Email: vuichard@gmail.com

Manuscript received 13 March 2009; manuscript accepted 13 November 2009. sensitive to climate change because it experiences strong water limitations during the growing season, and because its water balance is sensitive to changes in amount and timing of water input by winter snowfalls. From the results of 20 Intergovernmental Panel on Climate Change climate models, Central Eurasia is projected to undergo a $21 \%$ increase in wet-season (November-April) rainfall variability and a $16 \%$ increase in growing-season (May-October) rainfall variability, accompanied by a $10 \%$ decrease of the mean growing-season rainfall amount (Giorgi 2006). These changes will have a significant impact on ecosystem functioning, in particular on evapotranspiration and carbon-water interactions. In particular, one may anticipate that regional climate change described by Giorgi and others will likely cause a decrease of grassland productivity, as more variable climate is observed to be paralleled by lower productivity (Fang et al. 2005). The increase in temperature together with diminished growing season rainfall, and increased growing season length, is expected to increase 
evapotranspiration and water stress significantly above today's level. Golubev et al. (2001) reported that the actual evapotranspiration has already increased in steppe and forest vegetation sites in southern Russia at a rate of about $5 \%$ per decade.

In this context, both field data and ecosystem models describing the fluxes of $\mathrm{CO}_{2}$, water and energy, and the carbon and water pools, are needed to quantify and understand the Central Eurasian steppe response to climate, and its potential vulnerability to future climate change. Model-data fusion techniques can be developed to improve models by adjusting their parameters to fit optimally the observations (Santaren et al. 2007; Carvailhais et al. 2008) and by assessing structural deficiencies of models (Abramowitz 2005). This process may, in turn, guide the development of new parameterizations or help to refine the existing ones. Here we focus on identification of shortcomings and improvements of a generic process-oriented model with the use of $3 \mathrm{yr}$ of new eddy-covariance observations in 2002-2004. This flux data set constitutes a unique record of $\mathrm{CO}_{2}$ and $\mathrm{H}_{2} \mathrm{O}$ fluxes over an unmanaged Central Asian drysteppe ecosystem, in the Hakasia region of southern Russia. In addition to these $3 \mathrm{yr}$ of eddy-covariance fluxes, satellite observations of the fraction of absorbed photosynthetically active radiation (FAPAR) from the SEAWIFFS-FAPAR global satellite product (Gobron et al. 2006) sampled at the flux-tower site, are used to evaluate the model's phenology.

Although there is a wide variety of forest process-oriented ecosystem models (Tiktak and Van Grinsven 1995), processbased models of grasslands are scarcer (Parton et al. 1993; Riedo et al. 1998; Thornley 1998). In addition, most of these grassland models have been developed for site-scale applications, where they allow encapsulation of a large number of small-scale processes, but the large input data requirements for these models may not be practical for regional or continental scales. An alternative choice assumed in this study is to pick up a generic vegetation model, and to improve its parameterization regionally, against site-specific observations. Overall, the main objective of this article is thus to improve the ability of a generic vegetation model (ORCHIDEE) to reproduce the observed $\mathrm{CO}_{2}$ and water fluxes at the Hakasia steppe ecosystem.

ORCHIDEE (Krinner et al. 2005) belongs to the family of global vegetation models (DGVM) that are developed and applied for simulating land/atmosphere interactions. These models are often used for global or large-scale carbon budget analysis (McGuire et al. 2001; Ciais et al. 2005) and for predicting past and future trajectories of the coupled carbonclimate system (Cramer et al. 2001; Friedlingstein et al. 2006; Sitch et al. 2008). The performances of DGVM models remain however to be carefully checked against multiple-scale observation of the carbon, nutrients, water, and energy cycles. This is why persistent efforts are made for testing and evaluating DGVM at site scale, for instance, against eddy-covariance measurements (Thornton et al. 2002; Jung et al. 2007). In this site-scale testing configuration, the model is usually forced by local weather and climate drivers and by local vegetation and soil conditions (Kucharik et al. 2000; Thornton et al. 2002; Krinner et al. 2005).

After a description of the new eddy-covariance measurements made at the Hakasia steppe site between 2002 and 2004 and of the FAPAR remote-sensed data, we present the ORCHIDEE model and the specific parameterization we developed for steppe ecosystem. We then present the first model-data comparison for growth primary productivity (GPP) and leaf area index (LAI) for the years 2002 to 2004. Last, the results of the parameterization in terms of water and carbon fluxes and of interannual variability are presented.

\section{METHODS}

\section{Data From Hakasia Steppe, Southern Russia}

General Characteristics. The Hakasia eddy-covariance site is located $30 \mathrm{~km}$ north of the town of Shira (lat $54^{\circ} 43^{\prime} \mathrm{N}$, long $90^{\circ} 00^{\prime} \mathrm{E}$ ) in the Iyus-Shira region of the Republic of Hakasia. It is a natural graminoid small-tussock steppe that was extensively managed as a pasture until 2001 . However, because of the low grazing pressure, no major sign of disturbance over the vegetation composition and structure, compared to sites with no grazing history, was found. The soil is classified as a calcic chernozem (second-level legend FAO-Unesco) with fine surface texture and a proportion of clay ranging between $35 \%$ and $60 \%$ (Stolbovoi 2000).

The climate at the site, according to the Koppen climate classification system (Thornthwaite 1933), is semiarid cool (BSk). Climatic statistics determined on the base of archive data of Shira for the period 1942-1995 reveal a mean annual temperature of $0.4^{\circ} \mathrm{C}$ and a seasonal temperature cycle characterized by a very large continentality (difference between mean temperature of January and July is $35^{\circ} \mathrm{C}$ ) and annual precipitation of $304 \mathrm{~mm}$, out of which $245 \mathrm{~mm}$ is distributed during the growing season from May to September.

Climate and Ecosystem Conditions During the Eddy-Flux Measurement Period. During the 3 consecutive years of measurement, 2002, 2003, and 2004, the average annual temperature was $2.9^{\circ} \mathrm{C}, 1.6^{\circ} \mathrm{C}$, and $2.3^{\circ} \mathrm{C}$, respectively. The mean annual precipitation was $341 \mathrm{~mm}, 425 \mathrm{~mm}$, and $388 \mathrm{~mm}$, respectively. Year 2002 is characterized by temperatures from January to March above the average, with little precipitation in late spring-early summer (May-June) and a remarkably dry month in May (5.9 mm). Year 2003 shows in contrast a very rainy period at the beginning of the growing season (May: $57.3 \mathrm{~mm}$; June: $115 \mathrm{~mm}$ ) and an average climatic record during the rest of the year. Year 2004 is marked by a dry month of July $(60 \mathrm{~mm})$ with only $2 / 3$ of the rain received in the 2 previous years and a warmer than normal temperature in September and October.

On 4 March 2004, the steppe was burned. The soil was still frozen and soil temperature at a depth of $5 \mathrm{~cm}$ was $-11.8^{\circ} \mathrm{C}$. After a field survey in April it was noted that only the grass stem biomass was burnt, but no evidence of underground burning was found. At the date of the first biomass sampling (1 May 2004), the growing season had still not begun, as evidenced by the absence of live aboveground biomass. Because of the fire, the dead aboveground biomass was $0.39 \mathrm{t}$ dry matter $\cdot \mathrm{ha}^{-1}$, a value by far lower than the typical amount of dry grass recorded during previous years at the same site in spring.

Net Ecosystem Exchange (NEE) Measurements. Measurements of NEE by eddy-covariance technique started in July 2002 and lasted until December 2004, with some breaks during cold 
months (January-April 2003, November-April 2004) when there was no vegetative activity. Details of instrumental setup, acquisition mode, and data processing techniques are described in Belelli-Marchesini (2007) and Belelli-Marchesini et al. (2007).

Continuous measurements of wind speed, sonic temperature, $\mathrm{CO}_{2}$ concentration, and water-vapor density (VPD) were carried out on-line with a set of instruments including a 3-D sonic anemometer (1012R3; Gill Instruments, Hampshire, United Kingdom) and a fast-response open-path infrared gas analyzer (IRGA; LI7500, LiCor Inc, Lincoln, NE) mounted on the top of a $4.5-\mathrm{m}$ tower. $\mathrm{CO}_{2}$ flux $\left(F_{\mathrm{c}}\right)$ was calculated according to Aubinet et al. (2000), accounting for air density according to the equation of Webb et al. (1980).

Flux-time series were screened for the detection of anomalous values arising from sensor malfunctioning caused in particular by interference of water condensation, raindrops, or insects with the optical path of the IRGA. Spikes that remained in the half-hourly data set were detected by using an algorithm as in Papale et al. (2006) and using the $z$ values set to 5.5. Data gaps included also rejected NEE values associated to turbulence conditions below a threshold defined according to Reichstein et al. (2005) and Papale et al. (2006).

Gap-Filling Procedure. Gaps in the data set due to instrument maintenance and calibration, power outages, blockage of the system, removal of spikes, bad-quality data, and fluxes associated with low turbulence conditions totaled 39\%, $26.5 \%$, and $28 \%$ during the monitoring periods of 2002, 2003, and 2004, respectively. The gap-filling procedure is performed by applying the marginal distribution sampling (MDS) method (Reichstein et al. 2005). In the MDS method, given the fact that meteorological data were available without gaps, missing values of NEE were replaced by average values under similar meteorological conditions within a time window of $\pm 7 \mathrm{~d}$. Similar meteorological conditions are present when global radiation $\left(R_{\mathrm{g}}\right), T_{\mathrm{air}}$, and VPD do not deviate by more than $50 \mathrm{~W} \cdot \mathrm{m}^{-2}, 2.5^{\circ} \mathrm{C}$, and $5.0 \mathrm{hPa}$, respectively. If no similar conditions were present within the time window the averaging window was increased and similar conditions were defined only based on $R_{\mathrm{g}}$ or simply the measurement time (see Reichstein et al. 2005 for details).

NEE Partitioning. With negative NEE values indicating carbon fluxes from atmosphere to ecosystem, the partitioning of NEE into the component of GPP and total ecosystem respiration (TER) was obtained as

$$
\mathrm{GPP}=\mathrm{TER}-\mathrm{NEE}
$$

TER was retrieved by applying the algorithm by Reichstein et al. (2005), which derives a short-term temperature sensitivity of TER from eddy-covariance data based on the exponential regression model (Lloyd and Taylor 1994):

$$
\mathrm{TER}=\mathrm{TER}_{\text {ref }} \exp \left\{E_{0}\left[1 /\left(T_{\text {ref }}-T_{0}\right)-1 /\left(T-T_{0}\right)\right]\right\}
$$

Regressions were performed for subperiods of $15 \mathrm{~d}$, with consecutive time windows overlapping $10 \mathrm{~d}$, in order to estimate the temperature sensitivity parameter $E_{0}$, setting the reference temperature to $10^{\circ} \mathrm{C}$ and keeping constant the parameter $T_{0}$ at $-46.02^{\circ} \mathrm{C}$ as in Lloyd and Taylor (1994). After an $E_{0}$ parameter representative for the whole monitoring period was estimated, the temperature-independent level of respiration $\left(\mathrm{TER}_{\mathrm{ref}}\right)$ was estimated for consecutive 4-d periods by nonlinear regression with the use of the Lloyd and Taylor model, fixing all parameters except TER ${ }_{\text {ref }}$ TER $_{\text {ref }}$ parameters estimated were assigned to the "center of gravity" of the data of each period and were then linearly interpolated between the estimates producing a continuous time series.

\section{Remote-Sensing Data of the FAPAR}

The FAPAR product that we use has been developed by assuming that the spectral properties of leaves and soil correspond to the photosynthetic active radiation (PAR) region, which is between $400 \mathrm{~nm}$ and $700 \mathrm{~nm}$. In this case, simulations are made with a homogeneous canopy model (Gobron et al. 1997) representing land surfaces, coupled with the atmospheric radiative transfer model 6S (Vermote et al. 1997). Because green vegetation strongly absorbs solar radiation in the red spectral region, and strongly scatters it in the near infrared, these two bands are the main ones used to characterize land surfaces from remote-sensing data. The reflectance in the blue band is sensitive to the aerosol's optical thickness and, therefore, is used to decontaminate the red and the near-infrared bands from atmospheric effects. The product, available globally at a spatial resolution of $6 \mathrm{~km}$ (mean of $3 \times 3$ pixels at a $2-\mathrm{km}$ resolution) each $10 \mathrm{~d}$ (http://fapar.jrc.it), was sampled at the flux-tower location from 2002 to 2004. The FAPAR were converted into LAI by the following equation: FAPAR $=$ $1-e^{(-k \mathrm{LAI})}$ with $k=0.5$ (Monsi and Saeki 1953).

\section{Organizing Carbon and Hydrology in Dynamic Ecosystems (ORCHIDEE) Model Description}

ORCHIDEE is a process-oriented multiecosystem model (Krinner et al. 2005). It calculates surface $\mathrm{CO}_{2}, \mathrm{H}_{2} \mathrm{O}$, and heat fluxes (half-hourly), and water and carbon pools (daily), in response to weather and climate, rising $\mathrm{CO}_{2}$, and land-cover changes. The model contains a biophysical module dealing with photosynthesis and energy-balance calculations (half-hourly; Ducoudré et al. 1993), a module predicting leaf onset as a function of climate (Botta et al. 2000), autotrophic respiration (Ruimy et al. 1996), carbon allocation (Friedlingstein et al. 1999), and heterotrophic respiration derived from the CENTURY model (Parton et al. 1988). As in most DGVM models, the vegetation is described with the use of plant functional types (PFTs). PFTs follow the same set of governing equations with different parameter values, except for the calculation of the growing season onset and termination, which involves a PFT-specific equation (Botta et al. 2000).

The main limitations of ORCHIDEE are that 1) nutrient cycling is not modeled, 2) grassland or grazing management effects are not included, 3) the soil hydrology module uses a simple two-layer bucket scheme, which may produce erroneous soil moisture content in summer drought episodes, 4) the snow module is a simple one-layer scheme, with no inclusion of snow microphysics and liquid-water content, which may not account for springtime soil-moisture variations, and 5) it uses a PFT approach and partially ignores the effects of species dynamics on ecosystem carbon and water fluxes. 
The ORCHIDEE model has been used to calculate the distribution of carbon fluxes regionally, with a focus over western Europe (Ciais et al. 2005; Morales et al. 2005; Reichstein et al. 2007), and globally (Friedlingstein et al. 2006; Sitch et al. 2008). This model has been evaluated against measurements of eddy-covariance fluxes (Ciais et al. 2005; Krinner et al. 2005; Friend et al. 2007; Jung et al. 2007; Santaren et al. 2007) and against biomass and soil carbon-pool measurements in forests (Gervois et al. 2004; Loustau et al. 2005). This is the first time that ORCHIDEE has been used for a steppe ecosystem, and the model has not been tuned for this particular type of vegetation. All the steppes, temperate and cold grasslands, are given the parameter vector and equations of the PFT C3-grasses (Krinner et al. 2005). Grassland management (grazing, cutting, fertilization) is not included in our simulation, but, as shown above, the measurement site was very extensively grazed before 2001 and left ungrazed since then. We give here the set of equations related to the photosynthesis, allocation, and phenology for the C3 grass PFT.

Assimilation. Photosynthesis $\left(A_{n}\right)$ is calculated after the Farquhar et al. (1980) equation for C3 plants, as

$$
A_{n}=V_{c}\left(1-\Gamma_{*} / C_{i}\right)-R_{d}
$$

where $V_{c}\left(\mu \mathrm{mol} \cdot \mathrm{m}^{-2} \cdot \mathrm{s}^{-1}\right)$ is the rate of carboxylation, $\Gamma$ * (ppm) is the $\mathrm{CO}_{2}$ compensation point when there is no nonphotorespiratory respiration, $R_{d}\left(\mu \mathrm{mol} \cdot \mathrm{m}^{-2} \cdot \mathrm{s}^{-1}\right)$ is the rate of nonphotorespiratory respiration, and $C_{i}$ is the $\mathrm{CO}_{2}$ concentration at the carboxylation site. The rate of carboxylation $V_{c}$ is expressed by the more limiting factor between ribulose-1,5-biphosphate (RuBP) activity $W_{c}$ and RuBP regeneration $W_{j}\left(\mu \mathrm{mol} \cdot \mathrm{m}^{-2} \cdot \mathrm{s}^{-1}\right)$. The maximum rates of $\mathrm{RuBP}$ carboxylation $\left(V_{c \max }\right)$ and regeneration $\left(V_{j \max }\right)$ are parameterized as a function of leaf age, increasing from a relatively low initial value to a prescribed optimum parameter $\left(V_{c \text { max,opt }}\right.$ or $\left.V_{\text {jmax,opt }}\right)$ during the first days after leaf onset, staying at constant at this maximum for a given period (a few months, depending on the PFT), and then decreasing to a lower value for old leaves (Ishida et al. 1999). In ORCHIDEE, the parameters $V_{c \text { max,opt }}$ and $V_{\text {jmax,opt }}$ are set to 80 and $160 \mu \mathrm{mol} \cdot \mathrm{m}^{-2} \cdot \mathrm{s}^{-1}$, respectively, for the C3 grass PFT. Water stress is accounted for in the formulation of $V_{c \max }$ and $V_{j \max }$ following McMurtrie et al. (1990). Moreover, plants optimizing their vertical distribution of nitrogen naturally, in order to favor the canopy levels where light is the most abundant, $V_{c \max }$ and $V_{j \max }$, also decrease with increasing LAI. They are both parameterized as an exponentially decreasing function of canopy depth with an asymptotic minimum limit of $30 \%$ of the minimum efficiency after Johnson and Thornley (1984).

Phenology. To define the leaf onset, different models are used according to the PFT considered (Botta et al. 2000). For C3 grass, the leaf-onset calculation depends on the climate zone. In cool regions $\left(T<10^{\circ} \mathrm{C}\right)$ such as the Hakasia site, a simple growing-degree-day criterion is used. Following Botta et al. (2000), the pertinent cutoff temperature for grasses is $-5^{\circ} \mathrm{C}$, and growing-degree-days are counted over the whole dormancy season. The critical sum of growing degree days to be exceeded depends on the PFT and on the multiannual mean temperature
(MAT), as grasses in boreal regions need to accumulate less heat before starting their growth. For C3 grasses, this critical growing-degree-days threshold is $185^{\circ} \mathrm{C}$ day for $\mathrm{MAT}=0^{\circ} \mathrm{C}$ and $400^{\circ} \mathrm{C}$ day for MAT $=30^{\circ} \mathrm{C}$.

Senescence of leaves and fine roots is treated in a rather simple way. Two different criteria are used separately to calculate the fraction of leaves and roots that dies at a given time step. The first criterion is meteorological, depending on recent temperature and/or water stress. The second criterion is related to the fact that even if meteorological conditions are kept favorable for leaf maintenance, plants have to renew their leaves simply because old leaves become inefficient. In consequence, a fraction of the leaves and fine roots is lost every time step as a function of the leaf age. The fraction of biomass affected by senescence is defined by

$$
\Delta B=B \min \left[0.99, \frac{\Delta t}{a_{c}}\left(\frac{a}{a_{c}}\right)^{4}\right],
$$

where the parameter $a_{c}$ is the critical leaf age, $a$ the current leaf age, $\Delta t$ the time step, and $B$ the leaf biomass at previous time step. For the C3 grass PFT, the default critical age value is $a_{c}=120 \mathrm{~d}$. The formulation above ensures quite rapid loss of leaves when their age approaches the critical age threshold.

Allocation. The basic hypothesis is that the plant will allocate carbon to its different tissues essentially in response to external limitations: water availability $\left(A_{b}\right)$, light $\left(A_{l}\right)$, and nitrogen availability $\left(A_{n}\right)$. Water availability is calculated supposing an exponential root length profile decreasing with depth, independent of the fine root mass. Light limitation is a function of the weighted mean LAI of the natural PFTs present in the grid box. This is based on the idea that a plant will "see" around itself the LAI of the other plants present in the grid box and will have to compete against these for light. Nitrogen limitation is parameterized as a function of monthly soil humidity and monthly soil temperature, as in the work of Friedlingstein et al. (1999). The basic idea is that plant available nitrogen will depend on microbial activity in the soil, which itself depends on humidity and temperature. The belowground availabilities $A_{n}$ and $A_{b}$ are then combined to a single belowground availability $\left(A_{b}\right)$. The two availabilities $\left(A_{l}\right.$ and $\left.A_{b}\right)$ are then used to calculate preliminary allocation fractions for leaves, roots, and sapwood, $f_{l}, f_{r}$, and $f_{s}$, respectively, as follows:

$$
\begin{aligned}
& f_{r}=\max \left(r_{\min }, r_{0} \frac{3 A_{l}}{A_{l}+2 A_{b}}\right) \\
& f_{s}=s_{0} \frac{3 A_{b}}{2 A_{l}+A_{b}}, \\
& f_{l}=\max \left[a_{\min }, \min \left(a_{\max }, 1-f_{r}-f_{s}\right)\right]
\end{aligned}
$$

with $r_{\min }=0.15, a_{\min }=0.2, a_{\max }=0.8$, and $r_{0}=s_{0}=0.3$. The preliminary root allocation fraction is then recalculated to obtain $f_{l}+f_{r}+f_{s}=1$.

The underlying idea is that the stronger a given stress, the more carbon will be allocated to the corresponding tissue (e.g., 
to roots in the case of drought). Allocation fractions may be modified in some special cases. For instance, during the growth period, if the LAI is higher than a prescribed maximum LAI parameter $\mathrm{LAI}_{\max }$ (arbitrarily fixed to 2.5 for all C3 grasses), then no carbon will be further allocated to the leaves, no matter what the limitations are. In this case, $f_{s}$ equals $f_{s}+f_{l}$ and $f_{l}$ is set to zero. Similarly, if a plant reaches near the end of its growing season (i.e., it undergoes meteorological leaf senescence), then there is no point in allocating carbon to leaves or roots. The whole assimilate will then be attributed to the carbohydrate reserve pool $f_{c}=1$, while all the other allocation fractions are set to zero. The carbohydrate reserve is only used at the beginning of the growing season in order to attain a reasonable leaf cover rapidly. If the plant is at the beginning of its growing season (i.e., if the detection of the beginning of the growing season took place not longer than $30 \mathrm{~d}$ ago for grasses), and if the $\mathrm{LAI}$ is lower than $\mathrm{LAI}_{\text {max }} / 2$ (value of $\mathrm{LAI}_{\text {init }}$ parameter), then carbon is translocated from the carbohydrate reserve to the leaves and roots. The quantity of translocated reserves is commonly such that without additional photosynthesis, the plant would attain an LAI equal to $\mathrm{LAI}_{\max } / 2$ within 2 wk after budburst.

\section{Simulations Setup}

Forcing Variables. The model input variables are soil texture, atmospheric $\mathrm{CO}_{2}$ levels, and meteorological variables measured every $30 \mathrm{~min}$ (temperature, rainfall, net radiation, air relative humidity, and wind speed). In this study, the meteorological input data are those continuously measured on top of the eddy-covariance flux tower at Hakasia (lat $54^{\circ} 43^{\prime} \mathrm{N}$, long $\left.90^{\circ} 00^{\prime} \mathrm{E}\right)$.

Spin-Up Procedure. We first did a spin-up simulation to calculate the ecosystem steady-state equilibrium (long-term mean $\mathrm{NEE}=0$ ) during $\sim 1000 \mathrm{yr}$ with ORCHIDEE being forced by cycling the meteorological conditions of year 2002 and fixed $\mathrm{CO}_{2}$ concentration. This spin-up run is followed by a 3-yr simulation between 2002 and 2004 where hourly meteorological data are prescribed as input to the model. The use of a steady-state equilibrium initialization, which by construction leads to a near-zero long-term NEE, is justified by the fact that the ecosystem studied here is a natural steppe with very extensive management history and very low disturbance (very little grazing, no large fires, no erosion).

Parameter-Adjustment Procedure for Steppe Ecosystem. Given that the model has about 50 parameters, we need to choose which parameters must be modified for model adjustment against the Hakasia eddy-flux data and FAPAR satellite observation. Our list of parameters to be adjusted is based upon 1) expert judgment and discussion between modelers and experimentalists about the Hakasian site key features, and 2) the detailed sensitivity study of the model to all its parameters (Santaren et al. 2007). We chose to adjust a vector of eight parameters:

- $V_{c \text { max,opt }}$ and $V_{\text {jmax,opt }}$ the optimal photosynthesis capacities in absence of limitation by climate and leaf age

- The maximal turnover time $\left(\operatorname{turn}_{\max }\right)$ and leaf critical age $\left(a_{c}\right)$ when senescence begins,
- $\mathrm{LAI}_{\text {init }}$, the LAI value below which reserves are used; $a_{\max }$, the maximal leaf allocation fraction; and $s_{0}$, the preliminary shoot allocation fraction

- $\mathrm{LAI}_{\max }$, the maximum LAI (biome specific) that can be reached

Instead of using a Bayesian model optimization procedure to calibrate all parameters in the same step, we adjust each of them manually in a specific order. First, we adjust $\mathrm{LAI}_{\max }$ to fit the remote-sensing data of the FAPAR. Second, we modify the values of $\mathrm{LAI}_{\max }, s_{0}, a_{\max }$ and turn $\mathrm{max}_{\text {max }}$ and $a_{c}$ in order to better match, respectively, the onset and senescence phases of LAI. Last, we calibrate $V_{c \text { max,opt }}$ and $V_{\text {jmax,opt }}$ values against observed GPP (Belelli-Marchesini 2007; Belelli-Marchesini et al. 2007). Because corrections of the simulated GPP impacts plant respiration, soil heterotrophic respiration (through litter production and soil organic carbon decomposition), and to some extent water fluxes, latent heat flux (LH), TER, and NEE fluxes are recalculated with GPP optimal parameters and compared against observed values.

The strategy that we follow is to adjust the ORCHIDEE parameters against the flux data for year 2003 only, in order to keep some data for cross-validating the improved model for years 2002 and 2004. This cross validation is interesting because we adjust the model using only intra-annual flux variations in 2003, and will evaluate it against intra-annual and interannual variations for the 2 other yr.

\section{RESULTS AND DISCUSSION}

\section{Model-Data Comparison for LAI and GPP}

Comparison Over the Calibration Time Period. The modeled and observed GPP and LAI for 2003 are shown in Figure 1. Without parameter adjustment, ORCHIDEE overestimates GPP. From May to October 2003, the observed cumulated GPP is $444 \mathrm{~g} \mathrm{C} \cdot \mathrm{m}^{-2}$ and the calculated GPP is $1339 \mathrm{~g} \mathrm{C} \cdot \mathrm{m}^{-2}$ (Table 1). Thus, calculated GPP is three times higher than observed. However, the GPP seasonal cycle is rather well captured by ORCHIDEE with its onset in May and end date in October, and maximum values in July. The seasonal phase of LAI is seamlessly simulated, but maximum observed LAI (from SEAWIFFS-FAPAR) is $1.2 \mathrm{~m}^{2} \cdot \mathrm{m}^{-2}$, whereas modeled LAI reaches up to $2.5 \mathrm{~m}^{2} \cdot \mathrm{m}^{-2}$, implying that the $\mathrm{LAI}_{\text {max }}$ parameter value is realized in summer, because of the overestimation of GPP.

Based on the high-bias of model GPP (Fig. 1a) and LAI (Fig. 1b) for year 2003 and on expert knowledge, we modify the model parameters. First, we decrease $\mathrm{LAI}_{\max }$ from $2.5 \mathrm{~m}^{2} \cdot \mathrm{m}^{-2}$ to $1.2 \mathrm{~m}^{2} \cdot \mathrm{m}^{-2}$. Second, in order to reduce GPP and LAI at the beginning of the growing season, we set $\mathrm{LAI}_{\text {init }}$ to $\mathrm{LAI}_{\max } / 5$. Values of $s_{0}$ and $a_{\max }$ were set to 0.15 and 0.5 , respectively (e.g., $50 \%$ and $38 \%$ of reduction). To accelerate the decline of LAI during senescence, the critical leaf age $a_{c}$ is set to $60 \mathrm{~d}$ (i.e., $50 \%$ reduction from initial value). The maximal leaf turnover time is set to $40 \mathrm{~d}$ (a $50 \%$ reduction from initial value). Last, $V_{c \text { max,opt }}$ and $V_{\text {jmax,opt }}$ are reduced by $25 \%$ down to values of 60 and $120 \mu \mathrm{mol} \cdot \mathrm{m}^{-2} \cdot \mathrm{s}^{-1}$, respectively. 

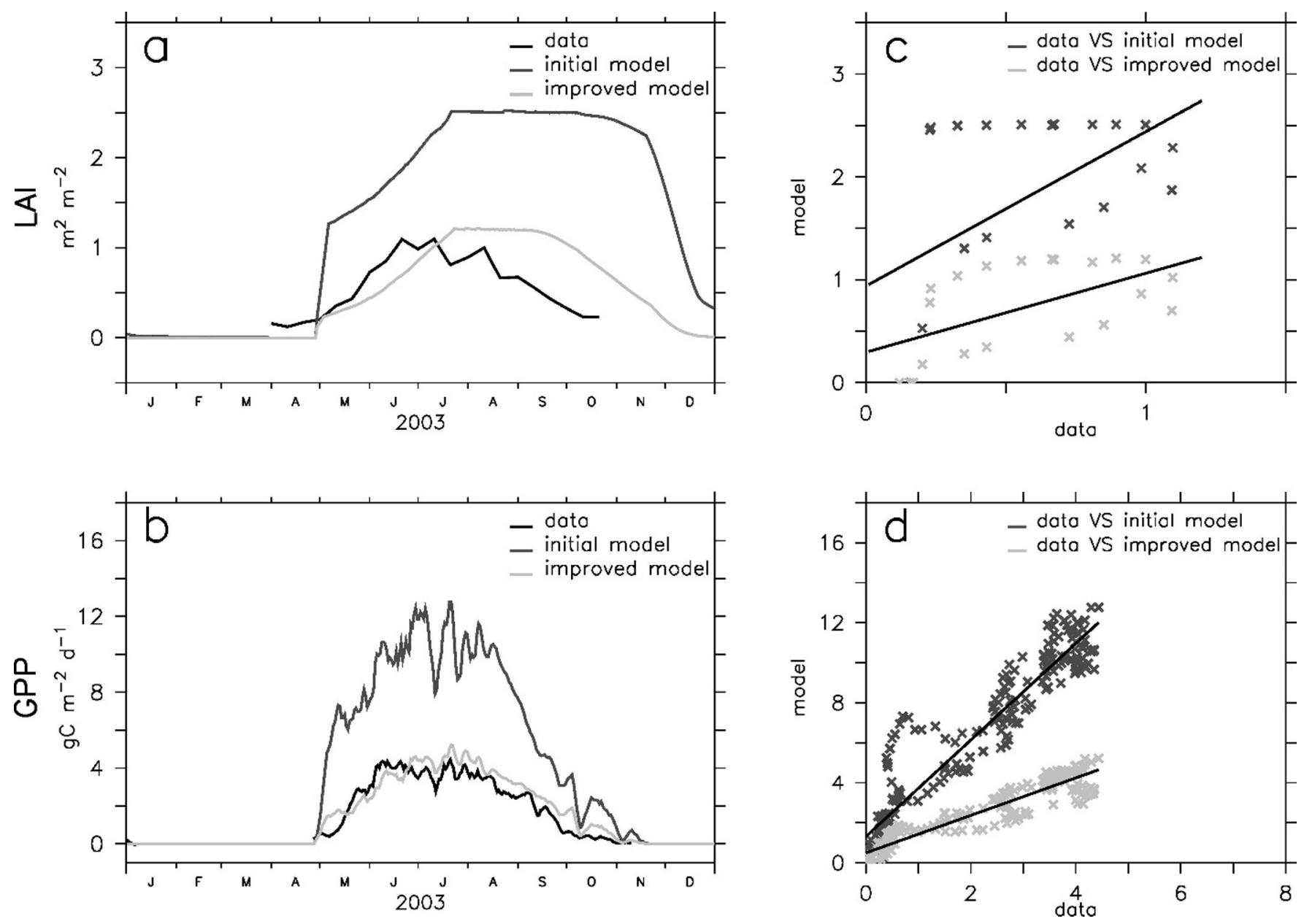

Figure 1. Five-day running mean of leaf area index (LAI) and growth primary production (GPP; left panels), as observed on Hak1 site (black), initially modeled by organizing carbon and hydrology in the dynamic ecosystems model (dark grey) and modeled after parameterization (light grey) and modeled vs. observed LAl and GPP (right panels) with the new parameterization (light grey) and without (dark grey) for the "calibrating" year 2003.

The simulated LAI resulting from all the above modifications is shown in Figure 1. The overall agreement with the data is quite satisfactory for the LAI seasonal dynamics. The simulated early-season growth of LAI is now smoother, in better agreement with the remote-sensing data. However, the declining phase of LAI still occurs too late. This model bias has also been identified by Krinner et al. (2005, fig. 8 ) and in the recent assimilation study of Demarty et al. (2007, fig. 2B). The slope of the model-data linear regression is 0.77 in the modified version, instead of initial value of 1.5 , with $R^{2}$ being stable at 0.3 . The intercept of the regression was reduced from 0.9 to 0.3 (reduced systematic bias). GPP after modification is shown in Figures $1 \mathrm{~b}$ and 1d. The cumulated GPP during the growing season (between May and October) is now in better agreement with the observation (see Table 1). The slope of the model-data linear regression line gets reduced from 2.4 to 0.9 , with $R^{2}$ being stable at 0.8 . Note that the late declining phase of LAI does not affect strongly the GPP decline, because at that time of the year, reduced day length and the high leaf age control the photosynthetic rates.

Cross Validation of Improved Model. We evaluate now how the improved parameterization performs for years 2002 and 2004, over which the model was not calibrated (Fig. 2). The

Table 1. Seasonal GPP, TER, NEE, and LH from June to October 2002, and from May to October 2003 and 2004 with data/old version (Model)/new version (Modif) of the ORCHIDEE model. ${ }^{1}$

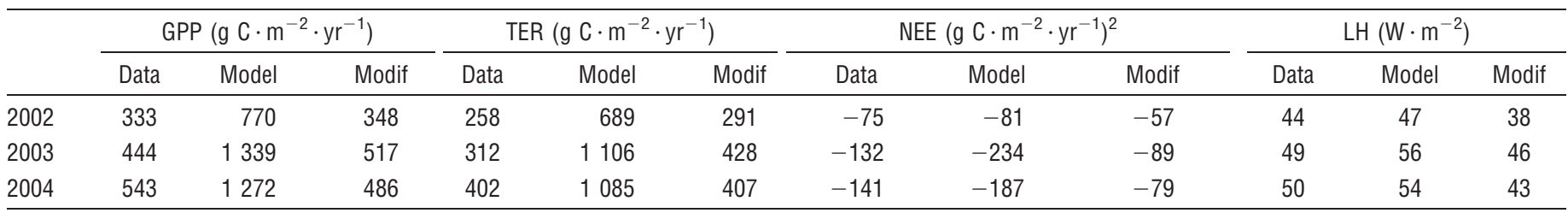

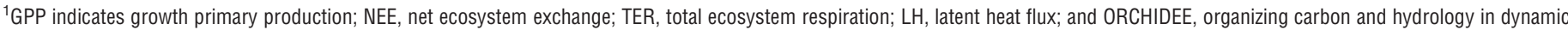
ecosystems model.

${ }^{2}$ Negative values indicate carbon fluxes from atmosphere to ecosystem. 

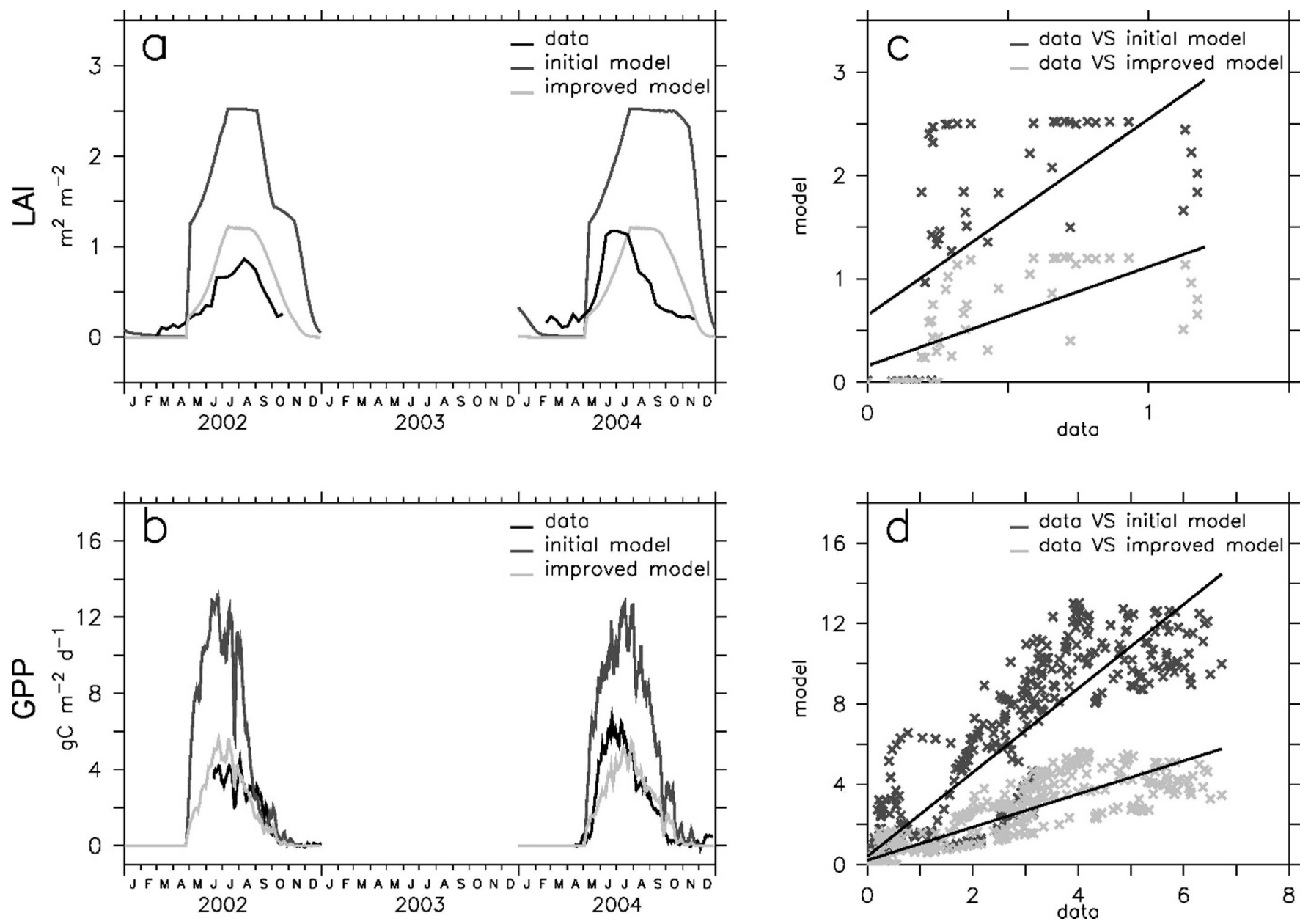

Figure 2. Five-day running mean of leaf area index (LAl) and growth primary production (GPP; left panels), as observed on Hak1 site (black), initially modeled by organizing carbon and hydrology in dynamic ecosystems model (dark grey) and modeled after parameterization (light grey) and modeled vs. observed LAI and GPP (right panels) with the new parameterization (light grey) and without (dark grey) for the "validating" years 2002 and 2004.

linear model-data regression of LAI has a slope of 0.96 $\left(R^{2}=0.46\right)$ during 2002 and 2004, which is an even better score than during the calibration year $\left(0.77 ; R^{2}=0.3\right)$. The late senescence bias is still present, however, during 2002 and 2004, suggesting a model structural deficiency (Fig. 2a). For GPP, the model performances over the cross-validation years are as good as during the calibration year (linear model-data GPP regression slope $\left.S=0.82 ; R^{2}=0.8\right)$. We conclude from this that our new settings of model parameters $\left(V_{c \text { max }, \text { opt }}, V_{\text {jmax }, \mathrm{opt}}, a_{c}, a_{\max }, s_{0}\right.$, and $\mathrm{LAI}_{\text {max }}$ ) suffice to improve LAI and GPP over the whole observation period. However, some interannual GPP and LAI anomalies remain (e.g., the fast early growing season in 2004 compared to years 2002 and 2003). The 2004 early growing season is likely affected by the small fire of March 4, which may have increased $V_{c \max }$ through a higher nitrogen availability (Wolf et al. 2006). This process is not included in ORCHIDEE, but seems to be of short duration, as the model performs well for LAI and GPP later in the growing season.

\section{Implications for TER and NEE Fluxes}

Up to now, our implemented modifications (phenology, allocation, photosynthesis processes) aimed at adjusting only
GPP and LAI in order to match the observations. Here, we quantify how these GPP improvements impact TER during the growing season and thus NEE. Figure 3 shows the new simulation of TER and NEE fluxes induced by the modified GPP. TER is now in much better agreement with the observed flux $\left(S=0.75\right.$ and $R^{2}=0.78$ vs. $S=1.94$ and $R^{2}=0.77$ in the initial version). Consequently, NEE also benefits from the improvements and shows a regression slope of 0.75 instead of 1.95 (Fig. 3). We conclude from this that the initial misfit between model and data for NEE was mostly due to biases in GPP. However, the lack of eddy-covariance observations does not allow us to draw any conclusion on the fit to TER during the winter period resulting from a more realistic GPP.

\section{Implications for Latent Heat Flux (LH)}

The data in Table 1 show that the simulation of $\mathrm{LH}$ is rather insensitive to model GPP (see also Fig. 3). Although $\mathrm{CO}_{2}$ and $\mathrm{H}_{2} \mathrm{O}$ fluxes are tightly coupled in ORCHIDEE, their ratio can vary during the growing season according to environmental conditions and water stress. Lower GPP and LAI in the improved model version reduce the summer peak of LH (Fig. 3). However, the response of LH is not proportional to 

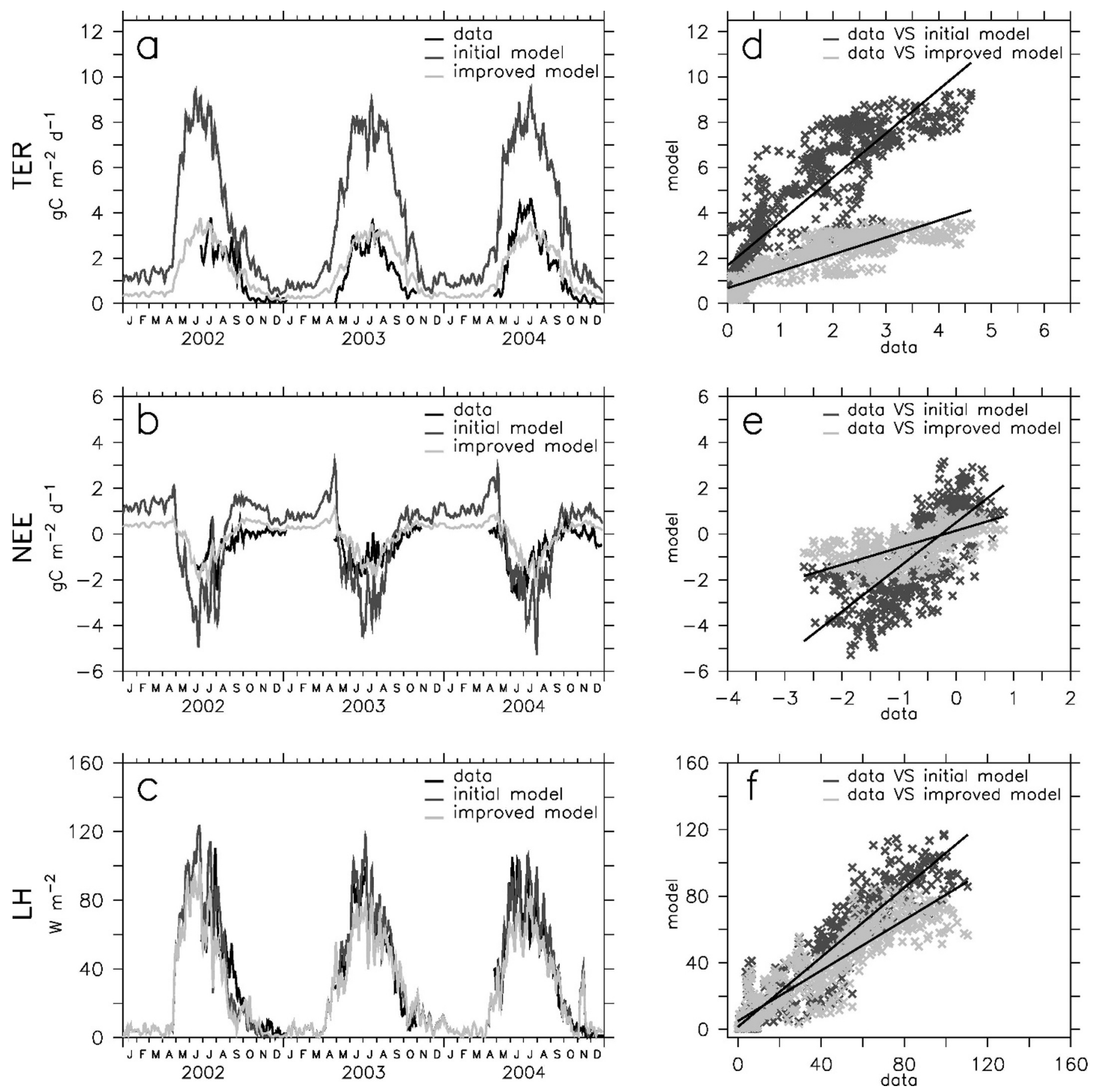

Figure 3. Five-day running mean of total ecosystem respiration (TER) (a), net ecosystem exchange (NEE) (b), and latent heat flux (LH) (c), as observed on Hak1 site (black), initially modeled by organizing carbon and hydrology in dynamic ecosystems model (dark grey) and modeled after parameterization (light grey) and modeled vs. observed TER (d), NEE (e), and LH (f) with the new parameterization (light grey) and without (dark grey) for the years 2002 to 2004.

that of GPP. Compensating effects during the different phases of the growing season, in particular unrealistic water savings achieved by lower LAI from spring to the dry summer, can explain why the simulation of $\mathrm{LH}$ is not improved $\left(R^{2}=0.82\right.$ in the new version vs. $R^{2}=0.88$ in the initial model).

\section{Interannual Variability of Fluxes}

Here we address the question of whether an improved seasonal cycle of GPP also improves interannual variability (IAV) of
GPP and other fluxes. This question is important to determine whether IAV of $\mathrm{CO}_{2}$ fluxes can be explained by environmental changes or by biotic responses (Richardson et al. 2007). We calculated an IAV model-data agreement index $I$ as

$$
I=\operatorname{mean}\left(\left|Y_{\text {model }}-Y_{\text {obs }}\right|\right) / \operatorname{mean}\left(Y_{\text {obs }}\right),
$$

where $Y$ is the mean flux of each year and the mean operator is applied over the full period 2002-2004. A perfect model-data 


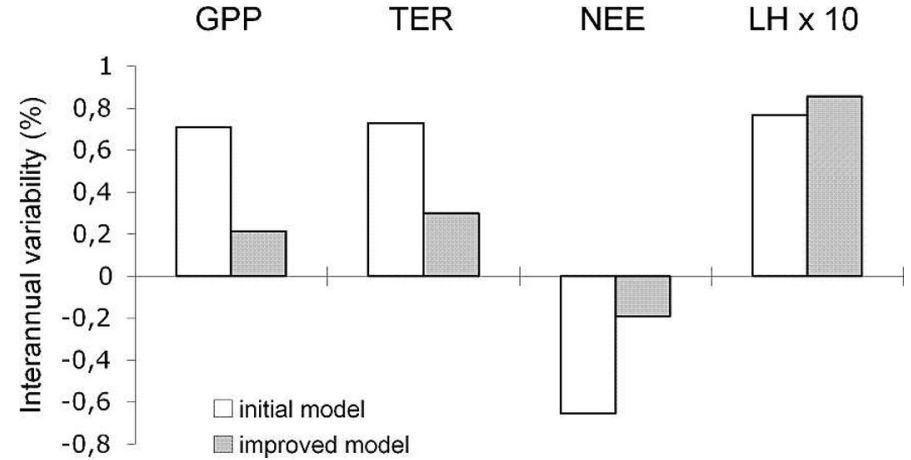

Figure 4. Interannual variability model-data comparison index (\%) for growth primary production (GPP), total ecosystem respiration (TER), net ecosystem exchange (NEE), and latent heat flux (LH) by using initial model (white columns) and improved model (grey columns).

agreement for IAV thus gives $I=0$. Figure 4 provides the value of $I$. Clearly, adjusting the model to obtain a better fit to seasonal GPP changes also results in a better IAV, as shown by $I$ values decreasing from 0.7 (initial version) to 0.2 (improved version). Similarly, agreement of IAV for TER and NEE shows improvement (from $I=0.7$ to 0.3 and from $I=0.65$ to 0.2 for TER and NEE, respectively).

These results suggest that at the Hakasia steppe site, the same biotic processes identified in our case to the same model parameters, control both the seasonal and the interannual response of the carbon balance to climate. An opposite conclusion was drawn from the three forest sites flux series investigated by Richardson et al. (2007) with the use of a diagnostic flux model. Although it is too early to generalize that the IAV of carbon fluxes is more directly controlled by climate in the steppe ecosystem than in the forest, more model applications to seasonal/interannual are needed.

It is also very interesting to observe that the single improvement of seasonal GPP dynamics also improves the IAV of TER. This indicates 1 ) that TER-IAV is tightly coupled to GPP-IAV in the steppes, and 2) that a model like ORCHIDEE, which includes carbon pool dynamics, is necessary to simulate the IAV signal faithfully. Finally, we note that NEE is the small difference between two large gross fluxes, each with a distinct seasonal sensitivity to climate. This makes it is more difficult for a model to reproduce the NEE-IAV than the GPP-IAV or TER-IAV. The fact that improving the seasonal cycle of GPP drives an improved NEE variability on both seasonal and interannual scales is very encouraging for the prospect of using estimates of LAI based on satellite data to constrain the steppe carbon balance.

\section{Selection of Adjusted Parameters}

The model initially overestimates GPP, due to both an overestimated LAI ( $81 \%$ of the GPP bias) and overestimated carboxylation rates (19\% of the GPP bias). The model was accordingly reparameterized by 1) reducing the summer maximum reachable LAI, 2) slowing down the early-season LAI growth and accelerating the late-season LAI senescence, and 3 ) reducing by $25 \%$ the optimal carboxylation rate constant parameters $V_{c \text { max,opt }}$ and $V_{\text {jmax,opt }}$. Our list of adjusted parameters is primarily based on expert judgment. For instance, we chose only to adjust $V_{c \text { max,opt }}$ and not the stomatal conductance parameters. Santaren et al. (2007) have shown that in ORCHIDEE, as in most models with the same level of complexity, determining optimal parameters is subject to "equifinality." Consequently, errors in stomatal conductance parameters (Ball et al. 1987) are highly negatively correlated with those of $V_{c \text { max,opt }}$, because of coupling between stomatal diffusion and photosynthesis equations. Similarly, because a 3yr record is a bit short to conclude whether the site is or not in steady-state equilibrium for its carbon pools (i.e., long-term mean NEE $=0$ ) we did not adjust any of the soil carbon pool scaling parameters (Santaren et al. 2007; Carvailhais et al. 2008) to avoid inducing an unrealistic disequilibrium between respiration and photosynthesis. Note, however, that by modifying $V_{c \text { max opt }}$ and $\mathrm{LAI}_{\max }$, the value of GPP is changed, which impacts the size of soil carbon pools and hence TER, thanks to the coupling between flux and carbon pools in the model. So, even GPP parameters have an indirect effect in setting the value of the TER flux.

Altogether, these parameter changes are sufficient to reproduce the observed day-to-day, seasonal, and interannual GPP variability faithfully. Yet, some model/data mismatches remain. For instance, the model overestimates GPP and LAI during the late growing season (i.e., in September). Several processes may explain this discrepancy. First, it might be due to an error in modeling the soil moisture during that period accurately, as suggested by a model/data comparison for the relative soil humidity in 2003 (not shown). However, over the whole season, the model agrees fairly well with the observations and performs much better for the relative humidity than initially for GPP and LAI. This explains why in our study we focus on adjusting phenological and photosynthetic parameters rather than on modifying the hydrological model. In fact, the hydrological model embedded into ORCHIDEE is a simple two-layer bucket model and is consequently relatively empirical. The future use of a more physically based soil model such as the one developed by de Rosnay et al. (2002) will certainly reduce the observed bias. Second, the observed bias for LAI and GPP might be due to an error when converting leaf mass into leaf area. In ORCHIDEE, the specific leaf area (SLA) is constant throughout the season, whereas in reality the SLA of young leaves is higher than that of old leaves. This finding is supported by the fact that the modeled LAI after adjustment is more correlated with the in situ measurements of live aboveground biomass (not shown) than with the remotely sensed LAI (see Figs. 1 and 2). From this, we may conclude that defining a variable SLA over the growing season into ORCHIDEE is required in order to correct for the observed bias between simulated and remote-sensed LAI and to match the observed GPP better.

\section{IMPLICATIONS}

The improved interannual variability of GPP suggests that ORCHIDEE can be tuned with the use of short-term flux data, and then integrated over a longer period to reproduce multiannual cumulative net fluxes. Further, we found that improving the seasonal cycle of GPP suffices to fit the observed TER and 
NEE flux data. From this, we conclude that $\mathrm{CO}_{2}$ and $\mathrm{H}_{2} \mathrm{O}$ fluxes from natural steppe ecosystems can be simulated with a generic DGVM model. Even without an explicit nitrogen cycle, the model is able to reproduce the observed interannual variability. After having been validated at regional scale against remotely sensed LAI and $\mathrm{CO}_{2}$ atmospheric concentration, the model improvements we performed for the steppe ecosystem will help to quantify the overall Central Eurasian steppe carbon balance better. This is of particular importance in the context of future climate change that might strongly impact the functioning of the steppes. Moreover, widespread land use changes took place over Central Eurasian steppes in the recent past history (e.g., cultivation period since the 1950s and farmland abandonment in the 1990s; Kolchugina et al. 1995) that have impacted the current carbon balance of these lands. The model's improvements presented in this study were a prerequisite to the model-based assessment of the land-useinduced soil carbon changes (Vuichard et al. 2008).

\section{LITERATURE CITED}

Aвramowitz, G. 2005. Towards a benchmark for land surface models. Geophysical Research Letters 32:L22702.1-L22702.4.

Aubinet, M., A. Grelle, A. Ibrom, U. Rannik, J. Moncrieff, T. Foken, A. S. Kowalski, P. H. Martin, P. Berbigier, C. Bernhofer, R. Clement, J. Elbers, A. Granier, T. Grunwald, K. Morgenstern, K. Pilegaard, C. Rebmann, W. Snijders, R. Valentini, AND T. VESALA. 2000. Estimates of annual net carbon and water exchange of European forests: the EUROLFUX methodology. Advances in Ecological Research 30:113-175.

Ball, J. T., I. E. Woodrow, and J. A. BerRy. 1987. A model predicting stomatal conductance and its application to the control of photosynthesis under different environmental conditions. In: I. Biggins [EDS.]. Progress in photosynthesis. Zoetermeer, Netherlands: Martinus Nijhoff Publishers. p. 221-224.

Belelli-MarchesinI, L. 2007. Analysis of the carbon cycle of steppe and old field ecosystems of Central Asia [thesis]. Viterbo, Italy: University of Tuscia. $209 p$.

Belelli-Marchesini, L., D. Papale, M. Reichstein, N. Vuichard, N. Tchebakova, and R. VALENTIII. 2007. Carbon balance assessment of a natural steppe of southern Siberia by multiple constraint approach. Biogeosciences 4:581-595.

Botta, A., N. Viovy, P. Cials, P. Friedlingstein, and P. Monfray. 2000. A global prognostic scheme of leaf onset using satellite data. Global Change Biology 6:709-725.

Carvalhais, N., M. Reichstein, J. Seixas, G. J. Collatz, J. S. Pereira, P. Berbigier, A. Carrara, A. Granier, L. Montagnani, D. Papale, S. Rambal, M. J. Sanz, and R. VALENTINI. 2008. Implications of the carbon cycle steady state assumption for biogeochemical modeling performance and inverse parameter retrieval. Global Biogeochemical Cycles 22:BG2007.1-BG2007.16.

Ciais, P., M. Reichstein, N. Viovy, A. Granier, J. Ogee, V. Allard, M. Aubinet, N. Buchmann, C. Bernhofer, A. Carrara, F. Chevallier, N. De Noblet, A. D. Friend, P. Friedlingstein, T. Grunwald, B. Heinesch, P. Keronen, A. Knohl, G. Krinner, D. Loustau, G. Manca, G. Matteucci, F. Miglietta, J. M. Ourcival, D. Papale, K. Pilegaard, S. Rambal, G. Seufert, J. F. Soussana, M. J. Sanz, E. D. Schulze, T. Vesala, and R. ValentinI. 2005. Europe-wide reduction in primary productivity caused by the heat and drought in 2003. Nature 437:529-533.

Cramer, W., A. Bondeau, F. I. Woodward, I. C. Prentice, R. A. Betts, V. Brovkin, P. M. Cox, V. Fisher, J. A. Foley, A. D. Friend, C. Kucharik, M. R. Lomas, N. Ramankutty, S. Sitch, B. Smith, A. White, and C. Young-Molling. 2001. Global response of terrestrial ecosystem structure and function to $\mathrm{CO}_{2}$ and climate change: results from six dynamic global vegetation models. Global Change Biology 7:357-373.

Demarty, J., F. Chevallier, A. D. Friend, N. Viovy, S. Piao, and P. Cials. 2007. Assimilation of global MODIS leaf area index retrievals within a terrestrial biosphere model. Geophysical Research Letters 34:15402-15402. de Rosnay, P., J. Polcher, M. Bruen, and K. Laval. 2002. Impact of a physically based soil water flow and soil-plant interaction representation for modeling large-scale land surface processes. Journal of Geophysical ResearchAtmospheres 107:ACL3.1-ACL3.19.

Ducoudré, N., K. Laval, and A. Perrier. 1993. SeCHIBA, a new set of parametrizations of the hydrologic exchanges at the land-atmosphere interface within the LMD atmospheric general circulation model. Journal of Climate 6:248-273.

Fang, J. Y., S. L. Piao, L. M. Zhou, J. S. He, F. Y. Wei, R. B. Mynenl, C. J. Tucker, and K. TAN. 2005. Precipitation patterns alter growth of temperate vegetation. Geophysical Research Letters 32:L21411.1-L21411.5.

Farquhar, G. D., S. V. Caemmerer, and J. A. Berry. 1980. A biochemical model of photosynthesis $\mathrm{CO}_{2}$ fixation in leaves of $\mathrm{C} 3$ species. Planta 149:78-90.

Friedlingstein, P., P. Cox, R. Betts, L. Bopp, W. Von Bloh, V. Brovkin, P. Cadule, S. Doney, M. Eby, I. Fung, G. Bala, J. John, C. Jones, F. Joos, T. Kato, M. Kawamiya, W. Knorr, K. Lindsay, H. D. Matthews, T. Raddatz, P. Rayner, C. Reick, E. Roeckner, K. G. Schnitzler, R. Schnur, K. Strassmann, A. J. Weaver, C. YoshiKaWa, and N. Zeng. 2006. Climate-carbon cycle feedback analysis: results from the (CMIP)-M-4 model intercomparison. Journal of Climate 19:3337-3353.

Friedingstein, P., G. Joel, C. B. Field, and I. Y. Fung. 1999. Toward an allocation scheme for global terrestrial carbon models. Global Change Biology 5:755-770.

Friend, A. D., A. Arneth, N. Y. Kiang, M. Lomas, J. Ogee, C. Rodenbeckk, S. W. Running, J. D. Santaren, S. Sitch, N. Viovy, F. I. Woodward, and S. Zaehle. 2007. FluXNET and modelling the global carbon cycle. Global Change Biology 13:610-633.

Gervois, S., N. de Noblet-Ducoudre, N. Viovy, P. Cials, N. Brisson, B. Seguin, and A. Perrier. 2004. Including croplands in a global biosphere model: methodology and evaluation at specific sites. Earth Interactions 8:1-25.

GIoRGI, F. 2006. Climate change hot-spots. Geophysical Research Letters 33:L08707.1-L08707.4.

Gobron, N., B. Pinty, 0. Aussedat, J. M. Chen, W. B. Cohen, R. Fensholt, V. Gond, K. F. Huemmrich, T. Lavergne, F. Melin, J. L. Privette, I. Sandholt, M. Taberner, D. P. Turner, M. M. Verstraete, and J. L. Widlowski. 2006. Evaluation of fraction of absorbed photosynthetically active radiation products for different canopy radiation transfer regimes: methodology and results using Joint Research Center products derived from SeaWiFS against ground-based estimations. Journal of Geophysical Research-Atmospheres 111:13110-13110.

Gobron, N., B. Pinty, M. M. Verstraete, and Y. Govaerts. 1997. A semi-discrete model for the scattering of light by vegetation. Journal of Geophysical Research 102:9431-9446.

Golubev, V. S., J. H. Lawrimore, P. Ya. Groisman, N. A. Speranskaya, S. A. Zhuravin, M. J. Menne, T. C. Peterson, and R. W. Malone. 2001. Evaporation changes over the contiguous United States and the former USSR: a reassessment. Geophysical Research Letters 28:2665-2668.

Ishida, A., A. Uemura, N. Koike, Y. Matsumoto, and A. Lal Hoe. 1999. Interactive effects of leaf age and self-shading on leaf structure, photosynthetic capacity and chlorophyll fluorescence in the rain forest tree, dryobalanops aromatic. Tree Physiology 19:741-747.

Johnson, I. R., AND J. Thornley. 1984. A model of instantaneous and daily canopy photosynthesis. Journal of Theoretical Biology 107:531-545.

Jung, M., M. Vetter, M. Herold, G. Churkina, M. Reichstein, S. Zaehle, P. Ciais, N. Viovy, A. Bondeau, Y. Chen, K. Trusilova, F. Feser, and M. Heimann. 2007. Uncertainties of modeling gross primary productivity over Europe: a systematic study on the effects of using different drivers and terrestrial biosphere models. Global Biogeochemical Cycles 21:GB4021.1-GB4021.12.

Kolchugina, T., T. Vinson, G. Gaston, V. Rozhrov, and A. Shvidenko. 1995. Carbon pools, fluxes, and sequestration potential in soils of the former Soviet Union. In: R. Lal, J. Kimble, E. Levine, and B. Stewart [EDS.]. Soil management and greenhouse effect. Boca Raton, FL, USA: Lewis Publishers. p. 25-40.

Krinner, G., N. Viovy, N. de Noblet-Ducoudre, J. Ogee, J. Polcher, P. Friedlingstein, P. Cials, S. Sitch, and I. C. Prentice. 2005. A dynamic global vegetation model for studies of the coupled atmosphere-biosphere system. Global Biogeochemical Cycles 19:GB1015.1-GB1015.33. 
Kucharik, C. J., J. A. Foley, C. Delire, V. A. Fisher, M. T. Coe, J. D. Lenters, C. YoungMolling, N. Ramankutty, J. M. Norman, and S. T. Gower. 2000. Testing the performance of a dynamic global ecosystem model: water balance, carbon balance, and vegetation structure. Global Biogeochemical Cycles 14(3): 795-825.

LLoYd, J., AND J. A. TAYLoR. 1994. On the temperature dependence of soil respiration. Functional Ecology 8:315-323.

Loustau, D., A. Bosc, A. Colin, J. Ogee, H. Davi, C. Francols, E. Dufrene, M. Deque, E. Cloppet, D. Arrouays, C. Le Bas, N. Saby, G. Pignard, N. Hamza, A. Granier, N. Breda, P. Cials, N. Viovy, and F. Delage. 2005. Modeling climate change effects on the potential production of French plains forests at the sub-regional level. Tree Physiology 25:813-823.

McGuire, A. D., S. Sitch, J. S. Clein, R. Dargaville, G. Esser, J. Foley, M. Heimann, F. Joos, J. Kaplan, D. W. Kicklighter, R. A. Meier, J. M. Melillo, B. Moore, I. C. Prentice, N. Ramankutty, T. Reichenau, A. Schloss, H. Tian, L. J. Williams, and U. Wittenberg. 2001. Carbon balance of the terrestrial biosphere in the twentieth century: analyses of $\mathrm{CO}_{2}$, climate and land use effects with four process-based ecosystem models. Global Biogeochemical Cycles 15:183206.

McMurtrie, R., D. Rook, and F. Kelliher. 1990. Modelling the yield of pinus radiata on a site limited by water and nitrogen. Forest Ecology Management 30:381-413.

MonsI, M., And T. SaekI. 1953. Über den Lichtfactor in der Pflanzengesell schaffen und seine bedeutung für die stoffproduktion. Japanese Journal of Botany 14:22-52.

Morales, P., M. T. Sykes, I. C. Prentice, P. Smith, B. Smith, H. Bugmann, B. Zierl, P. Friedlingstein, N. Viovy, S. Sabate, A. Sanchez, E. Pla, C. A. Gracia, S. Sitch, A. Arneth, and J. OGeE. 2005. Comparing and evaluating process-based ecosystem model predictions of carbon and water fluxes in major European forest biomes. Global Change Biology 11:2211-2233.

Papale, D., M. Reichstein, E. Canfora, M. Aubinet, C. Bernhofer, B. Longdoz, W. Kutsch, S. Rambal, R. Valentini, T. Vesala, and D. Yakir. 2006. Towards a more harmonized processing of eddy covariance $\mathrm{CO}_{2}$ fluxes: algorithms and uncertainty estimation. Biogeosciences 3:571-583.

Parton, W. J., J. M. 0. Scurlock, D. S. OJima, T. G. Gilmanov, R. J. Scholes, D. S. Schimel, D. S. Kirchner, J. C. Menaut, T. Seastedt, E. Garcia Moya, A. Kamnalrut, and J. L. Kinyamario. 1993. Observations and modeling of biomass and soil organic matter dynamics for the grassland biome worldwide. Global Biogeochemical Cycles 7:785-809.

Parton, W., J. Stewart, and C. Cole. 1988. Dynamics of C, N, P, and S in grassland soils: a model. Biogeochemistry 5:109-131.

Reichstein, M., P. Cials, D. Papale, R. Valentini, S. Running, N. Viovy, W. Cramer, A. Granier, J. Ogee, V. Allard, M. Aubinet, C. Bernhofer, N. Buchmann, A. Carrara, T. Grunwald, M. Heimann, B. Heinesch, A. Knohl, W. Kutsch, D. Loustau, G. Manca, G. Matteucci, F. Miglietta, J. M. Ourcival, K. Pilegaard, J. Pumpanen, S. Rambal, S. Schaphoff, G. Seufert, J. F. Soussana, M. J. Sanz, T. Vesala, and M. Zhao. 2007. Reduction of ecosystem productivity and respiration during the European summer 2003 climate anomaly: a joint flux tower, remote sensing and modelling analysis. Global Change Biology 13:634-651.

Reichstein, M., E. Falge, D. Baldocchi, D. Papale, M. Aubinet, P. Berbigier, C. Bernhofer, N. Buchmann, T. Gilmanov, A. Granier, T. Grunwald, K. Havrankova, H. Ilvesniemi,
D. Janous, A. Knohl, T. Laurila, A. Lohila, D. Loustau, G. Matteuccl, T. Meyers, F. Miglietta, J. M. Ourcival, J. Pumpanen, S. Rambal, E. Rotenberg, M. Sanz, J. Tenhunen, G. Seufert, F. Vaccari, T. Vesala, D. Yakir, and R. Valentini. 2005. On the separation of net ecosystem exchange into assimilation and ecosystem respiration: review and improved algorithm. Global Change Biology 11:1424-1439.

Richardson, A. D., D. Y. Hollinger, J. D. Aber, S. V. Ollinger, and B. H. Braswell. 2007. Environmental variation is directly responsible for short- but not longterm variation in forest-atmosphere carbon exchange. Global Change Biology 13:788-803.

Riedo, M., A. Grub, M. Rosset, and J. Fuhrer. 1998. A pasture simulation model for dry matter production and fluxes of carbon, nitrogen, water and energy. Ecological Modelling 105:141-183.

Ruimy, A., G. Dedieu, and B. Saugier. 1996. TuRC: A diagnostic model of continental gross primary productivity and net primary productivity. Global Biogeochemical Cycles 10:269-285.

Santaren, D., P. Peylin, N. Viovy, and P. Cials. 2007. Optimizing a process-based ecosystem model with eddy-covariance flux measurements: a pine forest in southern France. Global Biogeochemical Cycles $21 \mathrm{p}$.

Sitch, S., C. Huntingford, N. Gedney, P. E. Levy, M. Lomas, S. L. Piao, R. Betts, P. Cials, P. Cox, P. Friedlingstein, C. D. Jones, I. C. Prentice, and F. I. Woodward. 2008. Evaluation of the terrestrial carbon cycle, future plant geography and climate-carbon cycle feedbacks using 5 dynamic global vegetation models (DGVMs). Global Change Biology 14:2015-2039.

Stolbovol, V. 2000. Soils of Russia: correlated with the revised legend of the FAO soil map of the world and world reference base for soil resources. Laxenburg, Austria: IIASA, Research Report RR-00-13. 113 p.

ThornLey, J. H. M. 1998. Grassland dynamics. An ecosystem simulation model. Wallingford, United Kingdom: CAB International. $241 \mathrm{p}$.

Thornthwalte, C. W. 1933. The climates of the earth. Geographical Review 23:433-440.

Thornton, P., B. E. Law, H. Gholz, K. Clark, E. Falge, and D. Ellsworth. 2002. Modelling and measuring the effects of disturbance history and climate on carbon and water budgets in evergreen needle leaf forests. Agricultural and Forest Meteorology 113:185-222.

Tiktak, A., and H. J. M. Van Grinsven. 1995. Review of sixteen forest-soilatmosphere models. Ecological Modelling 83:35-53.

Vermote, E. F., D. Tanré, J. L. Deuzé, M. Herman, and J. J. Morcrette. 1997. Second simulation of the satellite signal in the solar spectrum: an overview. IEEE Transactions on Geoscience and Remote Sensing 35:675-686.

Vuichard, N., P. Ciais, L. Belelli, P. Smith, and R. Valentini. 2008. Carbon sequestration due to the abandonment of agriculture in the former USSR since 1990. Global Biogeochemical Cycles 22:GB4018.1-GB4018.8.

WebB, E. K., G. Pearman, and R. Leuning. 1980. Correction of flux measurements for density effects due to heat and water vapour transfer. Quarterly Journal of the Royal Meteorological Society 106:85-100.

Wolf, A., K. Akshalov, N. Saliendra, D. A. Johnson, and E. A. Laca. 2006. Inverse estimation of $V_{c}(\max )$, leaf area index, and the Ball-Berry parameter from carbon and energy fluxes. Journal of Geophysical Research-Atmospheres 111:D08S08.1-D08S08.18. 